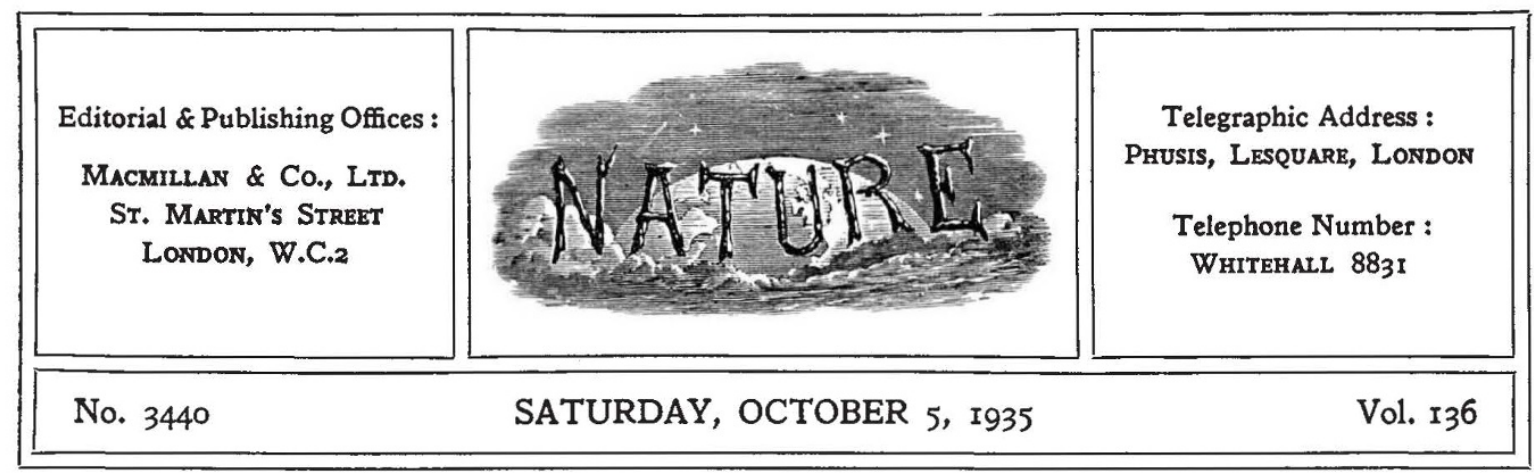

\title{
Organisation of Agricultural Research
}

STATE assistance to agricultural research in Great Britain began with the Development Act of 1909, and in accordance with the principle of that Act, the finance of the schemes then initiated remained with the Development Commission, while the administration rested with the departments of agriculture, until in 1930 the Agricultural Research Council was set up. This council, though equally under the Privy Council, has not quite the same status as its parallel bodies, the Department of Scientific and Industrial Research and the Medical Research Council, both of which administer directly the whole of the funds available from the Treasury for research in their subjects. It would be difficult to explain to a foreigner the curious machinery which now prevails for the purpose of making grants, involving as it does the Research Council, the Development Commission, the two departments of agriculture in England and Scotland, and finally the Treasury.

A recent article in Planning is very insistent on simplification, on the ground that all these separate strands of red tape not only result in delay in the consideration of applications for grants, but also are obstacles to the proper planning of agricultural research. Of course, no one would devise such an organisation de novo; it grew by stages, its excuse is the dread all Governments have of legislation, its justification is the necessity of maintaining continuous touch between the research workers and the agricultural departments, the administration of which should be guided by the conclusions reached by research. It may be doubted whether delays are greater than in any other dealings with a Government department. Speed of action is the attribute only of an autocracy, and of an autocracy on a small enough scale to allow of immediate access to the autocrat.
As to planning, it was for that purpose the Research Council was set up; it surveys the whole field, it reviews the work of each Institute, and though that Institute may be financed by the Development Commission and administered by the Ministry of Agriculture, it would scarcely be able to ignore the recommendations or criticism of the Council. As the writer in Planning admits, the cumbrous organisation is being made to work, and so it will remain until there comes along some Government willing to spare some of its precious 'time' in order to secure order and logic in its machinery of administration.

The article also discusses the failure to obtain any substantial addition to the funds for research from the farming community, but that is inevitable because of the way the industry is split up into small units of production. The Marketing Boards do possess powers of making a levy on their very considerable turnover that would raise ample funds for research, without imposing any perceptible burden upon the individual, but the awkward administrative question of reconciling the responsibility of the Council for the direction of research with the power of the purse possessed by the Marketing Boards is still unsettled.

The most weighty criticism of the Planning article is directed against the indifferent scale of salaries prevailing in the research institutes, which it is alleged are failing to attract men of initiative and high mental capacity. But as the head of one of our universities has pointed out, only a small fraction of the men who graduate each year are really of the first grade, a fraction well below the demand that is made upon the universities by the various services, business and professions. When, however, all allowance is made for this and for the fact that research 
offers a sheltered career with an attraction of its own, irrespective of income, there is undoubtedly much dissatisfaction among the agricultural research workers, a small body not more than five hundred in all, a large proportion of whom are not established. There is need for an unbiased review of the situation, and this is presumably within the reference of the Research Council. Agricultural research workers do need favourable terms, for they have few outlets for escape into well-paid business. It is precisely this alternative which renders recruiting for research in veterinary medicine so difficult in the veterinary profession; the great increase in administrative appointments of recent years has offered to any graduate of quality prospects much superior to those the research institutes can offer.

We doubt if the suggestion that the Research Council itself ought to appoint super-directors of its own for each group of subjects is helpful. The man in charge of a research station, the man who is immersed in the subject, may be guided and may benefit from the critical examination of his work by men of quality in the cognate pure sciences, but he cannot be made to work to order or forgo his responsibility. If one believes in research, one must trust the research worker's personality. The practical outcome of such a plan would be to withdraw the few outstanding men of originality from the active prosecution of research into administration.

The real function of the Research Council is not to control research nor to manage the research workers; it is to survey the field as a whole and to think out priorities, and to bring an enlightened judgment to bear upon the many proposals put be fore the Council. It has to decide whether the possibilities offered by the project are of the order of probabilities, and how far the pursuit of pure knowledge has an economic justification. Sometimes it will see a neglected opportunity, sometimes it must override a director in the interests of a more comprehensive organisation, sometimes it must advise a director that an investigation is becoming a routine, a blind alley. But ultimately it has to recognise that research is the product of the imagination and insight of individuals; its highest wisdom is to back the right horse.

Finally, the writer in Planning directs attention to the weakness of the organisation for getting the results of research passed over to the farmer and translated into action. It is a question which troubles the agricultural administration in every country, and particularly obsesses the public men concerned with agriculture. The inherent difficulty lies in the fact that agricultural production is split up among a number of relatively weak units, limited by lack of capital and personality. In agriculture there are no great corporations the resources of which enable them to take a long view about the adoption of a new process. The educational service which is in direct contact with farmers is outside the purview of the Research Council, and is doing excellent work. But the industry will have to become organised before it can reap the full harvest of research ; as the Marketing Boards gain experience, they will be able to press upon the producers, their members, the improved methods that are the outcome of investigation and knowledge.

\section{Study of Crystal Structure}

\section{A Study of Crystal Structure and its Appli- cations}

By Prof. Wheeler P. Davey. (International Series in Physics.) Pp. xi +695. (New York and London : McGraw-Hill Book Co., Inc., 1934.) 45s. net.

$A$ FTER a rather quiescent period, the study $\mathrm{A}$ of crystals sprang into great activity as soon as it was discovered that crystalline materials could be used as three dimensional gratings for radiation of the wave-lengths of $\mathrm{X}$-rays. The earlier work of crystallographers on the theory of space groups was presented in forms more useful for the new developments by Wyckhoff and by Astbury and Yardley. The Laue and Bragg methods, and the powder photographic method, were employed in the analysis of the internal structures of the simpler substances, and the subject advanced at a rapid rate.

As the substances examined increased in complexity, more data had to be obtained to permit of the deduction of their structures. Rotation and oscillation photographic methods were developed, special types of camera designed and much ingenuity displayed in devising reasonably quick graphical methods of interpreting the photographs; as 